\title{
China's 'eugenics' law still disturbing despite relabelling
}

As hoped, international discussions in Beijing on controversial family planning legislation have been productive. But China's law still gives grounds for worry.

$\int$ ust under ten years ago, the Chinese province of Gansu introduced a local law graphically described in its initial English translation as "prohibiting reproduction of dull-witted, idiots or blockheads". ror much of the intervening period, the Chinese government in Beijing has been attempting to draw up and put into practice a national law which, it claims, is aimed at the same public health objective, namely reducing the incidence of physical and mental disability, in particular through prenatal genetic screening. In doing so, China has raised considerable international hostility for efforts that some critics have even compared to those of Nazi eugenicists.

Much of this hostility has come from the genetics research community in the West, perhaps more sensitive than their Chinese counterparts to the abuses of their discipline in the past (including the recent revelations of enforced sterilization campaigns in apparently liberal countries such as Canada and Sweden). Professional societies in three countries - Britain, Argentina and Holland - registered their protest by boycotting the five-yearly International Congress of Genetics, which took place in Beijing last week (see page 711). Some individuals have suggested going further, by cutting off all research links with Chinese geneticists until the law, which came into force in 1995, is changed.

\section{Ambiguities}

One can have some sympathy for the Chinese defence that their strategy has been misinterpreted. Partly this was due to the naivety of an initial decision to describe the legislation, then in draft form, as a 'eugenics' law, apparently in ignorance of the negative connotations the word now carries in the West. Other misinterpretations appear to have been the result of ambiguities in the English translation of the final text of what is now known more benignly as the Law on Maternal and Infant Care. For example, it remains unclear whether a doctor's 'advice' on sterilization or ending a pregnancy is mandatory in cases where a "serious genetic disease" has been identified.

Furthermore, many of the law's articles about the need to provide adequate pre- and postnatal medical care for expectant mothers and children make good sense. Also, cultural differences in health-care delivery systems need to be respected. The traditional Chinese approach of treating a sick person not as an isolated individual, but as part of a family and a community, may not be aligned with the dominant views of western health-care providers; this does not mean, however, that such an approach is inevitably less effective.

But does this let China off the hook? Far from it. Even if the word 'eugenics' has been dropped from the official description of the law - and even if there is no explicit racist or political intent - it still contains elements and implications that are disturbing. One of these is the continuing lack of a clear definition of what is meant by "genetic disease of a serious nature". This omission can only increase the possibility of abuse. One Chinese bioethicist recalls being told by a local official in a remote region that three generations of mentally retarded individuals were sufficient to identify the syndrome as genetic - ignoring the possibility that the condition might be the result, not the cause, of the poverty in which the family was living.

Similarly, the law remains ambiguous, even in its revised form, on the extent to which couples will in practice be left free of pressure to accept or reject a recommended sterilization. Doubts about this are only strengthened by a recent international survey showing that genetic counsellors in China - in common with those in many other developing countries, including India and Egypt - strongly favour what is called 'directive counselling'. Paternalist traditions remain strong in Chinese medicine, and few have the inclination to challenge their doctor's judgement.

\section{Geneticists implicated}

Two other elements in the current situation give pause for thought. One concerns the role of geneticists who, far from being ignored in drawing up the law, in fact played a key role in the process. Suspicion has been voiced in some quarters that, in their desire to distance themselves from the ideas of the Russian geneticist Trofim Lysenko, whose dismissal of genes as 'bourgeois ideology' dominated Chinese science for two decades, the geneticists may have ended up making overoptimistic promises about the extent to which their discipline is in a position to make an immediate contribution to public health.

Finally, there is the continuing danger that the provisions in the law could, without sufficient safeguards, allow genetic arguments to be used as a smokescreen for sanctions against potentially disruptive ethnic groups, for example Tibetan nationalists. There is no evidence yet that this has taken place; indeed those who accuse the Chinese authorities of using family planning rules against ethnic minorities often forget that they are applied more strictly to the Han majority. But, given concerns elsewhere about respect for human rights in China, and continuing nervousness within the country itself about allowing open debate on controversial topics, nothing should be taken for granted in the current circumstances.

Having said all that, the picture is not entirely discouraging. There is evidence that the Chinese authorities responsible for the law have been listening carefully to the criticisms of outsiders. This is particularly true of comments relating to apparent discrepancies between provisions in its text and the principles enshrined in various international codes of behaviour - such as the United Nations Universal Declaration of Human Rights - which China has agreed to sign as part of its entry ticket as a full member of the international trade community. Certainly, as far as geneticists are concerned, prolonged sniping over the law has cast an unwelcome shadow over some efforts to establish international collaborations.

The next congress of the International Genetics Federation takes place in Melbourne, Australia, in 2003. By then, it will be clearer whether fears about the implementation of China's new law have been exaggerated or justified. Meanwhile, the international debates stimulated by these fears have served to highlight some of the contentious issues that are surfacing as the techniques of genomic analysis become ever more sophisticated. Provoking reflection on these has been a positive step. $\square$ 